\title{
The Microbiome in Hidradenitis Suppurativa: A Review
}

\author{
Kirsty J. L. Wark · Geoffrey D. Cains
}

Received: October 7, 2020 / Published online: November 26, 2020

(C) The Author(s) 2020

\begin{abstract}
Introduction: Hidradenitis suppurativa (HS) is a chronic autoinflammatory skin disease. It is characterised by the development of abscesses and nodules in intertriginous anatomical sites. Whilst it is now recognised as an autoinflammatory condition rather than an infective disease, bacteria are implicated in disease pathogenesis.

Methods: We performed a search of the literature from inception to 12 August 2020 using the search terms "hidradenitis suppurativa", "Verneuil's disease", "acne inversa", "microbiome", "bacteriology" and "microbiology". Studies were included if they assessed the cutaneous, gut or oral bacteria, bacteriology or microbiome in hidradenitis suppurativa.

Results: Twenty-one studies examining the cutaneous microbiome and two studies examining the gastrointestinal microbiome in HS were identified. No studies examining the oral microbiome in HS were identified. A total of 972 patients and 46 healthy controls were included across studies examining the cutaneous
\end{abstract}

K. J. L. Wark $(\varangle) \cdot$ G. D. Cains

Department of Dermatology, Liverpool Hospital, Sydney, Australia

e-mail: kirsty.jl.wark@gmail.com

K. J. L. Wark · G. D. Cains

School of Medicine, University of New South Wales, Sydney, Australia microbiome. A total of 100 patients and 36 controls were included across both gut microbiome studies. Coagulase-negative Staphylococcus, anaerobes such as Porphyromonas and Prevotella, and Staphylococcus aureus species were commonly encountered organisms across the included cutaneous microbiome studies. The studies examining the gut microbiome were limited, with one small study demonstrating an alteration in the gut microbiome composition compared to controls. The other study found no alteration to the gut microbiome in patients with HS compared to those with inflammatory bowel disease (IBD) and HS, and IBD and/or psoriasis.

Conclusion: Research should be undertaken into the oral microbiome in HS. Further research should be undertaken examining the cutaneous and gut microbiome in HS, and its relationship with documented co-morbidities. Additionally, metagenomics-focused studies may help identify the relationship between microorganisms and host, and this may shed light on new pathways of disease pathogenesis. This may help identify potential future therapeutic targets.

Keywords: Bacteria; Hidradenitis suppurativa; Infections; Gastrointestinal microbiome; Microbiota 


\section{Key Summary Points}

Hidradenitis suppurativa is a chronic autoinflammatory skin disease characterised by the development of abscesses and nodules in intertriginous sites such as the axilla and groin.

Anaerobic bacteria, such as Prevotella and Porphyromonas, coagulase-negative Staphylococcus, and Staphylococcus aureus were commonly identified microorganisms in HS lesions. Studies used culture, 16S RNA or a combination of these two modalities to identify which organisms were present.

There is limited research examining the gut microbiome in HS. One very small study found an alteration in the gut microbiome in patients with HS compared to healthy controls, and the other study found no difference in the HS group compared to those in the psoriasis, IBD, psoriasis and IBD, and HS and IBD groups.

There were no studies identified which examined the oral microbiome in HS.

Further research is required to help us understand how the microbiome and alterations in its composition contribute to disease pathogenesis in HS. This may help identify potential future therapeutic targets.

\section{DIGITAL FEATURES}

This article is published with digital features to facilitate understanding of the article. You can access the digital features on the article's associated Figshare page. To view digital features for this article go to https://doi.org/10.6084/m9. figshare.13182875.

\section{INTRODUCTION}

Hidradenitis suppurativa (HS) is a chronic autoinflammatory skin condition characterised by recurrent abscesses and nodules in intertriginous anatomical sites, such as the axilla, groin and gluteal areas $[1,2]$. There is associated purulent and malodour discharge from these lesions in many patients, and it may be initially mistaken for an infective process [3]. There is often a significant delay between disease onset and diagnosis, and many cases are only first identified in the moderate to severe stage [4]. The disease has a number of disease and lifestyle associations, including metabolic syndrome, diabetes mellitus, obesity, polycystic ovarian syndrome and smoking [5-10].

The aetiology of HS is multifactorial. Contributing factors include genetics, environmental and lifestyle factors such as cigarette smoking, bacteria and hormonal influences $[3,11,12]$. It is characterised by follicular occlusion, which has classically been considered an initiating event. In this model of HS pathogenesis, follicular occlusion and epidermal cyst formation lead to follicular rupture, and secondary bacterial infection [11].

The cutaneous microbiome consists of a diverse variety of bacteria, fungi and viruses which inhabit human skin. Across and within individuals it is taxonomically varied, and variations are dependent upon anatomical site, host and environmental factors, and the type and abundance of associated adnexal structures such as apocrine, eccrine and sebaceous glands, and hair follicles [13]. This cutaneous microbiome extends as far down as the superficial subcutaneous tissue [14]. It exists in homeostasis with the host immune system, and may provide a mutually beneficial relationship: it is involved in regulatory cytokine production, the maintenance of the epidermal barrier, keratinocyte differentiation and homeostasis, inhibition of pathogen growth, induction of local regulatory $\mathrm{T}$ cells and enhancement of innate immunity $[15,16]$. Alterations in the composition in the microbiome, usually as a result of host and environmental factors, can shift it towards dysbiosis-a maladaptive state 
which may cause or contribute towards disease pathogenesis [17].

Gut microbiome dysbiosis has been implicated in a number of diseases, including inflammatory bowel disease (IBD), atherosclerosis, autism and asthma [18]. Intestinal bacteria play an important physiological role, and are involved in immunological signalling, host cell proliferation, intestinal endocrine functions, biosynthesis of hormones, vitamins and neurotransmitters, and dietary and drug metabolism, among others [18].

Alterations to the oral microbiome can result in periodontitis, in which there is an increase in anaerobic bacteria in the oral cavity and corresponding increase in local inflammatory mediators such as tumour necrosis factor alpha (TNF $\alpha$ ), interleukins (IL)-1, 2 and 8, and prostaglandins [19].

The role of the microbiome in HS remains an area under ongoing investigation. The use of antimicrobial agents in HS is a well-established treatment, despite HS now being recognised as an autoinflammatory rather than infective disease [20]. The microbiome has been implicated in the pathogenesis of HS, although the interaction between organisms and host remains to be fully elucidated.

\section{METHODS}

The purpose of this narrative review was to collate and review the available evidence examining the cutaneous, gastrointestinal and oral microbiome in hidradenitis suppurativa.

We searched Medline, PubMed, Google Scholar and Embase between for the period between 12 April and 12 August 2020 using the search terms "hidradenitis suppurativa", "Verneuil's disease", "acne inversa", "microbiome", "bacteriology" and "microbiology". Studies were included if they assessed the cutaneous, gut or oral bacteria, bacteriology or microbiome in hidradenitis suppurativa.

This article is based on previously conducted studies and does not contain any new studies with human participants or animals performed by any of the authors.
We have constructed tables (Tables 1, 2, 3) which include the main findings from each included study.

\section{RESULTS}

Twenty-one studies examining the cutaneous microbiome and two studies examining the gastrointestinal microbiome in HS were identified. A total of 972 patients and 46 healthy controls were included across studies examining the cutaneous microbiome. A total of 100 patients and 36 controls were included across both gut microbiome studies.

\section{The Cutaneous Microbiome in Hidradenitis Suppurativa}

See Tables 1 and 2 .

\section{The Gastrointestinal Microbiome}

See Table 3.

\section{The Oral Microbiome}

No studies were identified which examined the oral microbiome in HS.

\section{DISCUSSION}

\section{The Main Findings}

In the studies which utilised bacterial culture in their study design, Staphylococcus aureus, coagulase-negative Staphylococcus and Enterobacteriaceae species were commonly cultured [27-29, 32, 33]. In the studies utilising $16 \mathrm{~S}$ and $18 \mathrm{~S}$ to examine the cutaneous microbiome, Porphyromonas and Prevotella had increased abundance $[21,23,24]$. Porphyromonas, Prevotella and Corynebacterium were the most commonly encountered bacteria in HS tunnels [23]. Thomas et al. found that in patients with recalcitrant HS Corynebacterium, S. epidermidis, $S$. aureus and Prevotella were the most frequent organisms [31]. One study utilised 
Table 1 Cutaneous microbiome in HS: next-generation studies (NGS) and immunofluoresence (IF) and fluorescence in situ hybridisation (FSH)

\begin{tabular}{|c|c|c|c|}
\hline Study & Participants and methods & Anatomical location & $\begin{array}{l}\text { Most common bacteria and other } \\
\text { main findings }\end{array}$ \\
\hline $\begin{array}{l}\text { Riverain- } \\
\text { Gillet } \\
\text { et al. } \\
(2020) \\
{[21]}\end{array}$ & $\begin{array}{l}60 \text { patients and } 17 \text { controls } \\
\text { Swabs and } 16 \mathrm{~S} \text { ribosomal RNA (rRNA) } \\
\text { gene amplicon sequencing }\end{array}$ & $\begin{array}{l}\text { Axilla, inguinal folds and } \\
\text { gluteal cleft }\end{array}$ & $\begin{array}{l}\text { Increased anaerobes (such as } \\
\text { Prevotella), Actinomyces, } \\
\text { Campylobacter ureolyticus and } \\
\text { Mobilinucus } \\
\text { Reduced commensals including } \\
\text { Staphylococcus epidermidis, } \\
\text { Staphylococcus hominis, } \\
\text { Cutibacterium acnes and other } \\
\text { coagulase-negative staphylococci }\end{array}$ \\
\hline $\begin{array}{l}\text { Naik et al. } \\
\qquad(2019) \\
{[22]}\end{array}$ & $\begin{array}{l}12 \text { patients and } 5 \text { controls } \\
\text { Swabs and } 16 S\end{array}$ & $\begin{array}{l}\text { Axilla, gluteal crease, } \\
\text { inguinal crease and } \\
\text { inframammary fold }\end{array}$ & $\begin{array}{l}\text { Increased gram-negative and gram- } \\
\text { positive anaerobes. Reduced } \\
\text { Cutibacterium } \\
\text { Microbiome in Hurley stage I disease } \\
\text { similar to healthy controls }\end{array}$ \\
\hline $\begin{array}{l}\text { Ring et al. } \\
\qquad(2019) \\
{[23]}\end{array}$ & $\begin{array}{l}32 \text { patients } \\
\text { Swabs of HS tunnels during deroofing } \\
\text { and } 16 \mathrm{~S}\end{array}$ & Axilla and groin & $\begin{array}{l}\text { Porphyromonas, Prevotella and } \\
\text { Corynebacterium }\end{array}$ \\
\hline $\begin{array}{l}\text { Guet- } \\
\text { Revillet } \\
\text { et al. } \\
(2017) \\
{[24]}\end{array}$ & $\begin{array}{l}65 \text { patients } \\
\text { Swabs, aspirates and biopsies for affected } \\
\text { areas. Swabs for unaffected areas. } \\
\text { Cultures and } 454 \text { high-throughput } \\
\text { sequencing }\end{array}$ & $\begin{array}{l}\text { Axilla, inguinal fold, } \\
\text { gluteal fold, buttocks, } \\
\text { thighs and breast }\end{array}$ & $\begin{array}{l}\text { Prevotella and Porphyromonas. } \\
\text { Increased anaerobes and reduced } \\
\text { aerobes. Fusobacterium and } \\
\text { Parvimonas predominated in } \\
\text { Hurley stage III lesions }\end{array}$ \\
\hline $\begin{array}{l}\text { Ring et al. } \\
\qquad(2017) \\
{[25]}\end{array}$ & $\begin{array}{l}30 \text { patients and } 24 \text { controls } \\
\text { Biopsies of affected and unaffected areas. } \\
16 \text { and } 18 \mathrm{~S}\end{array}$ & $\begin{array}{l}\text { Groin and axilla. All } \\
\text { biopsies included a hair } \\
\text { follicle }\end{array}$ & $\begin{array}{l}\text { Increased Corynebacterium, } \\
\text { Porphyromonas and Peptoniphilus. } \\
\text { Reduced Propionibacterium }\end{array}$ \\
\hline $\begin{array}{l}\text { Guet- } \\
\text { Revillet } \\
\text { et al. } \\
(2014) \\
{[26]}\end{array}$ & $\begin{array}{l}82 \text { patients } \\
\text { Metagenomics and culture }\end{array}$ & $\begin{array}{l}\text { Inguinal fold, perineal, } \\
\text { buttocks, thigh, gluteal } \\
\text { fold, axilla, breast, } \\
\text { trunk and neck }\end{array}$ & $\begin{array}{l}\text { Stage I lesions: Staphylococcus } \\
\text { lugdensis. Stage II-III lesions: mixed } \\
\text { anaerobes, anaerobic actinomycetes } \\
\text { and streptococci of the milleri } \\
\text { group }\end{array}$ \\
\hline $\begin{array}{l}\text { Jahns et al. } \\
\qquad(2014) \\
{[2]}\end{array}$ & $\begin{array}{l}27 \text { patients } \\
\text { IF and FSH hybridisation on } \\
\text { retrospective histological samples }\end{array}$ & $\begin{array}{l}\text { Arm, axilla, buttocks, } \\
\text { genitals and other }\end{array}$ & $\begin{array}{l}\text { 63\% had bacterial colonisation. } 4{ }^{\prime}, 6- \\
\text { diamidino-2-phenylindole-positive } \\
\text { cocci were seen in } 71 \% \text { of samples } \\
\text { with biofilms and/or microcolonies. } \\
\text { Two cases of Propionibacterium } \\
\text { acnes-associated biofilms }\end{array}$ \\
\hline
\end{tabular}


Table 2 Cutaneous microbiome and HS: traditional culture method studies

\begin{tabular}{|c|c|c|c|}
\hline Study & $\begin{array}{l}\text { Participants and } \\
\text { methods }\end{array}$ & Methods & $\begin{array}{l}\text { Most common bacteria and other } \\
\text { main findings }\end{array}$ \\
\hline $\begin{array}{l}\text { Benzecry et al. } \\
\text { (2018) [27] }\end{array}$ & $\begin{array}{l}46 \text { patients } \\
\text { Swabs }\end{array}$ & $\begin{array}{l}\text { Axilla, inframammary folds, pubis, } \\
\text { genital, groin, intergluteal fold, } \\
\text { buttocks and perineum }\end{array}$ & $\begin{array}{l}\text { Enterobacteriaceae, Streptococcus, } \\
\text { Corynebacterium and Staphylococcus }\end{array}$ \\
\hline $\begin{array}{l}\text { Bettoli et al. } \\
\text { (2018) [28] }\end{array}$ & $\begin{array}{l}137 \text { patients } \\
\text { Swabs }\end{array}$ & Axilla, groin and perianal region & $\begin{array}{c}\text { Proteus, E. coli, S. epidermidis, } \\
\text { Streptococcus agalactiae and } \\
\text { Staphylococcus haemolyticus }\end{array}$ \\
\hline $\begin{array}{l}\text { Jamalpour, Saki } \\
\text { and Nozari } \\
\text { (2018) [29] }\end{array}$ & $\begin{array}{l}26 \text { patients } \\
\text { Swabs }\end{array}$ & $\begin{array}{l}\text { Axilla, groin, scalp, neck, buttock, } \\
\text { back, intermammary and perineal } \\
\text { region }\end{array}$ & $\begin{array}{l}\text { Staphylococcus aureus, diptheroids and } \\
\text { E. coli }\end{array}$ \\
\hline $\begin{array}{l}\text { Nikolakis et al. } \\
\text { (2017) [30] }\end{array}$ & $\begin{array}{l}50 \text { patients } \\
\text { Swabs }\end{array}$ & $\begin{array}{l}\text { Axilla, mammary, inguino-femoral, } \\
\text { buttock, perianal and other }\end{array}$ & $\begin{array}{l}\text { In stage I, } S \text {. aureus, obligate anaerobic } \\
\text { gram-negative rods and enterococci. } \\
\text { In stage II, Enterobacteriaceae, } \\
\text { obligate gram-negative rods and } \\
\text { coagulase-negative staphylococci. In } \\
\text { stage III disease, obligate anaerobic } \\
\text { gram-negative rods, } \\
\text { Enterobacteriaceae, streptococci and } \\
\text { S. aureus }\end{array}$ \\
\hline $\begin{array}{l}\text { Thomas et al. } \\
\text { (2016) [31] }\end{array}$ & $\begin{array}{l}76 \text { patients with } \\
\text { recalcitrant HS } \\
\text { Collection } \\
\text { methodology not } \\
\text { specified }\end{array}$ & $\begin{array}{l}\text { Axilla, groin, perineum, gluteal, } \\
\text { perianal, abdomen, thigh, mons } \\
\text { pubis, labia, vulva, breast, } \\
\text { inframammary fold, neck, chest, } \\
\text { scrotum, face and occiput }\end{array}$ & $\begin{array}{l}\text { Corynebacterium species, } \\
\text { S. epidermidis, } S \text {. aureus and } \\
\text { Prevotella }\end{array}$ \\
\hline $\begin{array}{l}\text { Hessam et al. } \\
\text { (2016) [32] }\end{array}$ & $\begin{array}{l}113 \text { patients } \\
\text { Swabs }\end{array}$ & Axilla, groin, gluteal and perineum & $\begin{array}{l}\text { Coagulase-negative staphylococcus, } \\
\text { S. aureus, Proteus mirabilis and } \\
\text { E. coli }\end{array}$ \\
\hline $\begin{array}{r}\text { Katoulis et al. } \\
\text { (2015) [33] }\end{array}$ & $\begin{array}{l}22 \text { patients } \\
\text { Percutaneous needle } \\
\text { aspiration }\end{array}$ & $\begin{array}{l}\text { Axilla, breast, perianal, groin, rectum, } \\
\text { buttocks and scalp }\end{array}$ & Staphylococcus and P. mirabilis \\
\hline $\begin{array}{l}\text { Matusiak, } \\
\text { Bieniek and } \\
\text { Szepietowski } \\
\text { (2014) [34] }\end{array}$ & $\begin{array}{l}69 \text { patients } \\
\text { Swabs }\end{array}$ & Axilla and perineum & $\begin{array}{l}\text { S. epidermidis, P. mirabilis, } S \text {. aureus } \\
\text { and Enterococcus faecalis }\end{array}$ \\
\hline $\begin{array}{l}\text { Sartorius et al. } \\
\text { (2012) [35] }\end{array}$ & $\begin{array}{l}10 \text { patients } \\
\text { Biopsies and agar gel } \\
\text { cultures from deeper } \\
\text { layers post } \mathrm{CO}_{2} \text { laser } \\
\text { ablation }\end{array}$ & Axilla and groin & $\begin{array}{l}\text { Coagulase-negative staphylococcus, } \\
\text { anaerobic gram-positive cocci and } \\
\text { Corynebacterium species }\end{array}$ \\
\hline
\end{tabular}


Table 2 continued

\begin{tabular}{|c|c|c|c|}
\hline$\overline{\text { Study }}$ & $\begin{array}{l}\text { Participants and } \\
\text { methods }\end{array}$ & Methods & $\begin{array}{l}\text { Most common bacteria and other } \\
\text { main findings }\end{array}$ \\
\hline $\begin{array}{l}\text { Lapins, } \\
\text { Jarstrand and } \\
\text { Emtestam } \\
\text { (1999) [36] }\end{array}$ & $\begin{array}{l}25 \text { patients } \\
\text { Biopsies and swabs } \\
\text { from deeper layers } \\
\text { post } \mathrm{CO}_{2} \text { laser } \\
\text { ablation }\end{array}$ & Axilla and perineal region & $\begin{array}{l}\text { Coagulase-negative staphylococci, } \\
\text { S. aureus and Peptostreptococcus. } \\
\text { Peptostreptococcus, P. acnes, } \\
\text { Lactobacillus species, Prevotella, } \\
\text { other Bacteroides species, } \\
\text { enterococci, group C haemolytic } \\
\text { streptococci and Enterobacteriaceae } \\
\text { were also encountered in the deepest } \\
\text { layer (level 3) }\end{array}$ \\
\hline $\begin{array}{l}\text { Brook and } \\
\text { Frazier } \\
\text { (1999) [37] }\end{array}$ & $\begin{array}{l}17 \text { patients } \\
\text { Aspirates or swabs }\end{array}$ & Axilla & $\begin{array}{l}\text { S. aureus, Peptostreptococcus prevotii, } \\
\text { Streptococcus pyogenes and Prevotella } \\
\text { melaninogenica }\end{array}$ \\
\hline $\begin{array}{l}\text { Jemec et al. } \\
\text { (1996) [38] }\end{array}$ & $\begin{array}{l}41 \text { patients } \\
\text { Aspirates }\end{array}$ & $\begin{array}{l}\text { Axilla, inframammary fold and genital } \\
\text { region }\end{array}$ & $\begin{array}{l}\text { S. epidermidis, S. aureus and } \\
\text { polymicrobial culture }\end{array}$ \\
\hline $\begin{array}{l}\text { Highet et al. } \\
\text { (1988) [39] }\end{array}$ & $\begin{array}{l}32 \text { patients } \\
\text { Swabs }\end{array}$ & Perineal region & $\begin{array}{l}\text { Streptococcus milleri, S. aureus and } \\
\text { anaerobic streptococci }\end{array}$ \\
\hline
\end{tabular}

Table 3 Gut microbiome and HS

\begin{tabular}{|c|c|c|c|}
\hline Paper & Participants & Methods & Main findings \\
\hline $\begin{array}{l}\text { Kam et al. } \\
\qquad(2020) \\
{[40]}\end{array}$ & 3 patients and 3 controls & $\begin{array}{l}\text { Faecal samples and } \\
\quad 16 S\end{array}$ & $\begin{array}{l}\text { Increased abundance of Bilophila and } \\
\text { Holdemania; decreased abundance of } \\
\text { Firmicutes, Lachnobacterium and } \\
\text { Veillonella in patients with HS compared } \\
\text { to controls }\end{array}$ \\
\hline $\begin{array}{l}\text { Eppinga } \\
\text { et al. } \\
(2016) \\
{[41]}\end{array}$ & $\begin{array}{l}17 \mathrm{HS}, 17 \mathrm{HS} \text { and IBD, } 29 \text { psoriasis, } \\
31 \mathrm{IBD} \text { and } 13 \text { psoriasis and IBD } \\
\text { patients and } 33 \text { controls }\end{array}$ & $\begin{array}{l}\text { Faecal samples and } \\
\text { quantitative } \\
\text { polymerase chain } \\
\text { reaction }\end{array}$ & $\begin{array}{l}\text { Intestinal microbiome in the psoriasis, IBD, } \\
\text { psoriasis and IBD, and HS and IBD groups } \\
\text { was characterised by a decrease in } \\
\text { Faecalibacterium prausnitzii and increase in } \\
\text { E. coli, but that this was not seen in the } \\
\text { HS-only group }\end{array}$ \\
\hline
\end{tabular}

immunofluorescence (IF) and fluorescence in situ hybridisation (FSH), which demonstrated the presence of biofilms, some of which were associated with $P$. acnes [2]. However, Ring et al. found a reduction in P.acnes in involved HS tissue compared to control [25].

Only two studies were identified which investigated the gastrointestinal microbiome in HS. 
Eppinga et al. found no decrease in $F$. prausnitzii or increase in E.coli in participants with HS in comparison to the other included groups, none of which included healthy controls [41]. Kam et al. found an increased abundance of Bilophila and Holdemania and decreased abundance of Firmicutes, Lachnobacterium and Veillonella in patients with HS compared to controls [40]. However, this study was very small, with only three participants each in the HS and control groups.

\section{Relevance of the Findings}

Both Porphyromonas and Prevotella are most prevalent organisms on mucosal surfaces, including in the oral cavity, colon and tongue [42]. Porphyromonas and Prevotella in the skin microbiome may contribute to the pathogenesis of HS through upregulation of antimicrobial peptide (AMP) secretion, which in turn increases keratinocyte proliferation and recruitment of macrophages and neutrophils [43]. Porphyromonas gingivalis is an oral periodontopathogen and is implicated in the pathogenesis of periodontitis. Relevant virulence factors in HS include biofilm formation and dipeptidyl peptidase 4 activity [44]. Prevotella largely activates $\mathrm{T}$ helper 17 (Th17) immune responses, and has been shown to increase production of IL-23 and IL-1, both of which are implicated in the pathogenesis of HS [45-47]. Riverain-Gillet et al. demonstrated the presence of Porphyromonas and Prevotella in normal controls, but only in $22 \%$ of this group (as an anaerobic cluster) in comparison to $61 \%$ of affected individuals [21]. Ring et al. did not find the presence of Porphyromonas in normal controls [25].

Interestingly, whilst HS tunnels and Crohn's disease (CD) fistulas occur in similar anatomical sites such as the perineum, there are differences in the microbial composition between the two [48]. HS tunnels, as demonstrated by Ring et al., are characterised by an increase in Porphyromonas and Prevotella, as well as the presence of biofilms [23, 48]. In comparison, CD tunnels are characterised by an increase in adherent-invasive E.coli, staphylococci, Streptococcus and
Corynebacterium species, in addition to reduced gut microbial diversity [48].

Staphylococcus aureus has previously been implicated in the pathogenesis of HS [38]. However, the role of $S$. aureus is now less clear. Dinh et al. found that individuals with HS were less likely to have $S$. aureus nasal colonisation than controls [49]. Katoulis et al. demonstrated no statistically significant increase in S. aureus nasal carriage in patients with Hurley stage III HS compared to those with stage I or II disease [50]. S. aureus has a clearer relationship with other skin diseases such as atopic dermatitis, where high rates of nasal carriage and clinical improvement after decolonisation are observed [51].

Unaffected skin in patients with HS has been shown to demonstrate alterations in the cutaneous microbiome in comparison to controls $[21,25]$. This suggests that changes in the composition of the local microbiome may precede and contribute to development of lesions, rather than altering the local microbiome via secondary colonisation. The cutaneous microbiome is also influenced by host immunity; alterations in the local microbiome have been demonstrated via inhibition of complement $5 \mathrm{a}$ (C5a) receptor [52].

The role of diet in skin disease suggests a relationship between the gut microbiome and skin disease, a skin-gut axis. A well-recognised example is the relationship between coeliac disease and dermatitis herpetiformis [53]. Metabolic syndrome, and by association a Western diet, is a common co-morbidity in HS [54]. As described in Table 2, Eppinga et al. demonstrated an alteration in the gut microbiome in the HS and IBD group [41]. However, only a single Hurley stage III patient was included in the HS and IBD group, and none in the HS-only group. A small-scale study of patients with HS positive for anti-Saccharomyces cerevisiae antigen (ASCA) IgG who underwent surgical management of lesions and were subsequently placed on a brewer's yeast-free diet were found to have remission of lesions whilst practising dietary avoidance $[15,55]$. A later study involving 37 patients following a yeast-exclusion diet for 6 years demonstrated that $70 \%$ of patients improved with no other treatment, and 
consumption of yeast-containing foods was temporally associated with development of symptoms [56]. Elevated levels of ASCA IgG and IgA have been identified in patients with HS, particularly those with severe disease, in comparison to patients with psoriasis and healthy controls [57]. ASCA positivity is associated with IBD, and IBD is a recognised co-morbidity of HS $[58,59]$. The relationship between ASCA, IBD and HS requires further exploration. Additionally, given the role of lifestyle modification in HS, such as weight loss and regular gentle exercise, the relationship between Saccharomyces cerevisiae dietary avoidance and HS should be elucidated further through largerscale studies as a potential low-risk intervention.

As discussed by Frew et al., the cutaneous and gastrointestinal microbiome is thought to contribute to the pathogenesis of HS through multiple pathways including production of metabolites, simulation of myeloid dendritic cells via $G$ protein coupled receptors, and as a triggering event to inflammation in predisposed individuals [60]. One study examining the peripheral blood bacterial composition of patients with HS and healthy controls found no significant difference [61]. This reinforces that any role of the gut or oral microbiome does not work directly via haematogenous spread, but rather through alterations in metabolic, immunological and inflammatory pathways.

The role of the microbiome in the pathogenesis of HS remains unclear. There is evidence that inflammation is the triggering event to follicular occlusion and subsequent follicular rupture and fistula formation [62]. Whether the dysbiosis and alternations in the local microbiome are pathogenic and a driver in the underlying inflammatory processes, or a result, remains to be elucidated.

\section{LIMITATIONS}

Defining what constitutes the "normal" cutaneous microbiome is an evolving area. The microbiota predominantly vary by anatomical location on the skin, rather than ethnicity or the use of common topical products [63]. The
Human Microbiome Project is a large-scale microbiome study aimed at characterising the "normal" human microbiome across a number of anatomical environments including the skin $[64,65]$. It is unlikely that a true normal microbiome exists, and it is likely to be varied within and across individuals at various stages of time. Therefore, comparisons with "normal healthy" controls may introduce identification bias into interpretation of the results.

There are many limitations of microbiome research in HS. Only a few studies in this review included patient demographic data such as smoking status and body mass index (BMI). Smoking has been demonstrated to have an effect on the intestinal microbiome, causing reduced diversity and alterations to the composition of commensal bacteria [66]. The intestinal microbiome in some studies has been found to be altered in comparison to individuals with a normal BMI [67]. However, no studies to date have examined the relationship between these factors and the microbiome in HS. Microbiome studies should include sufficient metadata in relation to age, sex, ethnicity, disease severity, anatomical location, concomitant medication, prior or concurrent antibiotic use and topical product use [68].

There was heterogeneity in the methodology employed across the studies included in this review article. Not all studies included information regarding patient demographics or disease severity. There was variation in the way that specimens were obtained (swabs, aspirates and/or biopsies) and the identification of bacteria was made (either cultures or metagenomics). It has been shown that there is variation in the bacteria identified on normal skin on swabs versus biopsies using 16S [69]. In that study by Prast-Nielsen et al., there was increased number of anaerobes identified on skin biopsy, such as Bacteroides, which likely reflects the composition of bacteria found in the dermis versus superficial sampling of the epidermidis or open lesions with swabs alone. This has implications in interpreting the results of findings of microbiome studies, as many studies have only included swabs. One study by Lapins et al. used $\mathrm{CO}_{2}$ laser to systematically remove layers of skin, and swab as they went down [36]. 
This demonstrated the presence of coagulasenegative Staphylococcus in the deeper layers, which are implicated in biofilm formation in HS [70]. This is important as the cutaneous microbiome extends as far down as the superficial subcutis-therefore inclusion of skin biopsies in future studies is important in capturing the true microbiome of the skin cross-sectionally.

Whilst cultures are an important tool in identification of bacteria, particularly in clinical settings, they have several limitations. It is estimated that $99 \%$ of bacteria cannot be grown on culture [71]. However, cultures remain important in research as adjuncts to newer methodologies such as metagenomics, in order to assist with interpretation of metadata and for contributing vital information to reference databases [72]. Additionally, cultures are a costeffective and non-invasive testing methodology in clinical practice, and inclusion of these in research is important to provide clinically relevant information for future practice.

Many studies used unaffected sites for culture or biopsy as part of their study protocol. However, as discussed by Frew et al., the definition of lesional, perilesional and non-lesional skin in HS is not standardised. Given the morphology of HS, with subcutaneous tunnels and fistulas, careful identification of uninvolved skin is required to avoid inadvertent sampling of affected tissue. As Frew further discusses, healthy controls should be matched as close as possible in relation to anatomical site, age, sex, smoking status and ethnicity [73].

The use of $16 \mathrm{~S}$ is beneficial in identifying the presence of an array of bacteria in comparison to the traditional method of bacterial culture. However, this technology does not identify all bacteria present, bacterial activity, nor host response [74]. It is a useful tool in examining some of the populations of bacteria implicated in cutaneous disease but is unable to shed light on the interactions between host and microbe. Further research using whole genome sequencing and RNA transcriptomics responses should be undertaken to better elucidate bacterial activity and the interplay between organism and host gene expression. Furthermore, standardised approaches to collection of affected and unaffected tissue within and across participants, and collection of associated baseline patient data, are crucial in interpretation of data and in minimising confounding factors [68]. Skin microbiome research is vulnerable to factors such as a collection methodology, storage, contamination and biases introduced via sequencing methods [75].

Biofilms and their role in disease pathogenesis of HS were outside of the scope of this review article but are deserving of mention in this discussion. It has been established that HS is a disease characterised by biofilm formation, which may be a significant trigger in the organism-host pathophysiological response $[76,77]$. Ring et al. demonstrated the increased bacterial aggregates via PNA-FSH in chronic HS lesions, and the presence of biofilms in both lesional and perilesional tissue [77]. Several bacteria have been shown to have biofilm formation as an established virulence factor, such as Porphyromonas and S. epidermidis [44, 78]. The treatment resistance of HS to antibiotics, particularly in moderate to severe disease, may be in part due to the presence of biofilms [12].

\section{IMPLICATIONS FOR FUTURE RESEARCH}

The influence of treatment on the local microbiome is an area worthy of exploration. Adalimumab is an anti-TNFa which has been shown to be an effective treatment in the treatment HS [79]. Studies have demonstrated that treatment with adalimumab causes alterations in the gut microbiome towards eubiosis in patients with CD [80, 81]. Treatment of psoriasis with biologics has been demonstrated to cause alterations in the local microbiome, shifting it back towards the microbial composition of healthy controls [82]. However, alterations to the oral, gut and cutaneous microbiome in patients with HS undergoing treatment (including with biological agents) have not yet been investigated. This may help identify if the cutaneous and gastrointestinal microbiome alter with treatment, and whether this precedes or follows clinically measurable improvement in skin lesions. On the basis of research in $\mathrm{CD}$ and psoriasis, we would anticipate that an alteration 
towards eubiosis in the cutaneous and gastrointestinal microbiome in HS would be demonstrated. However, whether changes towards eubiosis will be accompanied by clinical response in patients with HS to treatment remains to be known.

No studies have yet been conducted examining the oral microbiome in HS, and research should be targeted at this branch of microbiome research. The oral microbiome is understood to be implicated in systemic illnesses such as heart disease and gastrointestinal cancer [83, 84]. Periodontitis has been shown to be associated with psoriasis, pemphigoid and pemphigus [19].

Likewise, there has been very limited research into the role of the gastrointestinal microbiome in HS, with the exception of the two studies discussed in this paper.

Given the propensity for HS to affect the inguinal and genital area, future research examining alterations in the vaginal microbiome should be undertaken. This may help shed light on whether there is cross-colonisation between the vaginal mucosa and HS lesions, and in which direction that this may occur. Additionally, further comparative research between HS tunnels and CD fistulas may help identify potential shared underlying pathways of pathogenesis, given the propensity for both diseases to occur within the perianal and genital regions.

Psychiatric co-morbidities, such as depression and anxiety, are common in HS [85]. Whether these occur as a consequence of the physical and social difficulties associated with HS, or as a result of associated underlying systemic inflammation, remains unclear. As discussed previously, collection and analysis of metadata with the microbiological findings should be undertaken. This would assist with identifying if specific microbial populations and compositions are associated with co-morbid psychiatric diseases in patients with HS. This may help identify possible therapeutic targets for patients with a high burden of psychological illness in the setting of HS.

As discussed, future studies examining the cutaneous microbiome of HS should include both biopsies for NGS and swabs or aspirates for traditional culture methods, and use metagenomics where possible, with a view to the implementation of whole genome sequencing and transcriptomics. The use of swabs and traditional culture methods is important to continue to include in future research, given that this represents a low-cost and mostly non-invasive test for future clinical practice when assessing alterations in the microbiome before and after treatment as potential markers of treatment response. Examining the oral, gastrointestinal and cutaneous microbiomes concurrently in individuals with and without HS would assist in understanding the alterations towards dysbiosis, and potentially provide targets for future therapeutic interventions.

\section{ACKNOWLEDGEMENTS}

Funding. No funding or sponsorship was received for this study or publication of this article.

Authorship. All named authors meet the International Committee of Medical Journal Editors (ICMJE) criteria for authorship for this article, take responsibility for the integrity of the work as a whole, and have given their approval for this version to be published.

Disclosures. Dr Kirsty Wark has received a research grant from Sun Pharma and has undertaken paid work for AbbVie. Professor Geoffrey Cains has received research grants from Sun Pharma and AbbVie. He has been a paid speaker for the AbbVie Pharmaceutical company.

Compliance with Ethics Guidelines. This article is based on previously conducted studies and does not contain any new studies with human participants or animals performed by any of the authors.

Data Availability. Data sharing is not applicable to this article as no datasets were generated or analyzed during the current study. 
Open Access. This article is licensed under a Creative Commons Attribution-NonCommercial 4.0 International License, which permits any non-commercial use, sharing, adaptation, distribution and reproduction in any medium or format, as long as you give appropriate credit to the original author(s) and the source, provide a link to the Creative Commons licence, and indicate if changes were made. The images or other third party material in this article are included in the article's Creative Commons licence, unless indicated otherwise in a credit line to the material. If material is not included in the article's Creative Commons licence and your intended use is not permitted by statutory regulation or exceeds the permitted use, you will need to obtain permission directly from the copyright holder. To view a copy of this licence, visit http://creativecommons.org/licenses/by$\mathrm{nc} / 4.0 /$.

\section{REFERENCES}

1. Jemec GB. Hidradenitis suppurativa. NEJM. 2012;366(2):158-64.

2. Jahns AC, Killasli H, Nosek D, et al. Microbiology of hidradenitis suppurativa (acne inversa): a histological study of 27 patients. APMIS. 2014;122(9): 804-9.

3. Sabat R, Jemec GBE, Matusiak $Ł$, Kimball AB, Prens E, Wolk K. Hidradenitis suppurativa. Nat Rev Dis Prim. 2020;6(1):18.

4. Saunte D, Boer J, Stratigos A, et al. Diagnostic delay in hidradenitis suppurativa is a global problem. Br J Dermatol. 2015;173(6):1546-9.

5. Shlyankevich J, Chen AJ, Kim GE, Kimball AB. Hidradenitis suppurativa is a systemic disease with substantial comorbidity burden: a chart-verified case-control analysis. J Am Acad Dermatol. 2014;71(6):1144-50.

6. Phan K, Charlton O, Smith SD. Hidradenitis suppurativa and polycystic ovarian syndrome: systematic review and meta-analysis. Austral J Dermatol. 2020;61(1):e28-33.

7. Kromann CB, Ibler KS, Kristiansen VB, Jemec GB. The influence of body weight on the prevalence and severity of hidradenitis suppurativa. Acta Derm Venereol. 2014;94(5):553-7.
8. Sartorius K, Emtestam L, Jemec G, Lapins J. Objective scoring of hidradenitis suppurativa reflecting the role of tobacco smoking and obesity. Br J Dermatol. 2009;161(4):831-9.

9. Phan K, Charlton O, Smith S. Hidradenitis suppurativa and diabetes mellitus: updated systematic review and adjusted meta-analysis. Clin Exp Dermatol. 2019;44(4):e126-32.

10. Miller IM, Ellervik C, Vinding GR, et al. Association of metabolic syndrome and hidradenitis suppurativa. JAMA Dermatol. 2014;150(12):1273-80.

11. Napolitano $M$, Megna $M$, Timoshchuk EA, et al. Hidradenitis suppurativa: from pathogenesis to diagnosis and treatment. Clin Cosmet Investig Dermatol. 2017;10:105.

12. Scuderi N, Monfrecola A, Dessy LA, Fabbrocini G, Megna M, Monfrecola G. Medical and surgical treatment of hidradenitis suppurativa: a review. Skin Append Disord. 2017;3(2):95-110.

13. Balato A, Cacciapuoti S, Di Caprio R, et al. Human microbiome: composition and role in inflammatory skin diseases. Arch Immunol Ther Exp. 2019;67(1): $1-18$.

14. Nakatsuji T, Chiang H-I, Jiang SB, Nagarajan $H$, Zengler K, Gallo RL. The microbiome extends to subepidermal compartments of normal skin. Nat Commun. 2013;4(1):1-8.

15. Polkowska-Pruszyńska B, Gerkowicz A, Krasowska D. The gut microbiome alterations in allergic and inflammatory skin diseases-an update. J Eur Acad Dermatol Venereol. 2020;34(3):455-64.

16. Prescott SL, Larcombe D-L, Logan AC, et al. The skin microbiome: impact of modern environments on skin ecology, barrier integrity, and systemic immune programming. World Allergy Org J. 2017;10(1):1-16.

17. Levy M, Kolodziejczyk AA, Thaiss CA, Elinav E. Dysbiosis and the immune system. Nat Rev Immunol. 2017;17(4):219-32.

18. Lynch SV, Pedersen O. The human intestinal microbiome in health and disease. N Engl J Med. 2016;375(24):2369-79.

19. Macklis P, Adams K, Kaffenberger J, Kumar P, Krispinsky A, Kaffenberger B. The association between oral health and skin disease. J Clin Aesthet Dermatol. 2020;13(6):48-53.

20. Vekic DA, Cains GD. Hidradenitis suppurativa, a review of pathogenesis, associations and management. Part 2. Austral J Dermatol. 2018;59(4):261-6. 
21. Riverain-Gillet É, Guet-Revillet H, Jais J-P, et al. The surface microbiome of clinically unaffected skinfolds in hidradenitis suppurativa: a cross-sectional culture based and 16S rRNA gene amplicon sequencing study in 60 patients. J Investig Dermatol. 2020;140(9):1847-55.e6.

22. Naik HB, Jo J-H, Paul M, Kong HH. Skin microbiota perturbations are distinct and disease severity-dependent in hidradenitis suppurativa. J Investig Dermatol. 2019;140(4):922-5.e3.

23. Ring H, Sigsgaard V, Thorsen J, et al. The microbiome of tunnels in hidradenitis suppurativa patients. J Eur Acad Dermatol Venereol. 2019;33(9): 1775-80.

24. Guet-Revillet H, Jais J-P, Ungeheuer M-N, et al. The microbiological landscape of anaerobic infections in hidradenitis suppurativa: a prospective metagenomic study. Clin Infect Dis. 2017;65(2):282-91.

25. Ring HC, Thorsen J, Saunte DM, et al. The follicular skin microbiome in patients with hidradenitis suppurativa and healthy controls. JAMA Dermatol. 2017;153(9):897-905.

26. Guet-Revillet H, Coignard-Biehler H, Jais J-P, et al. Bacterial pathogens associated with hidradenitis suppurativa, France. Emerg Infect Dis. 2014;20(12): 1990.

27. Benzecry V, Grancini A, Guanziroli E, et al. Hidradenitis suppurativa/acne inversa: a prospective bacteriological study of 46 patients and review of the literature. G Ital Dermatol Venereol. 2020;155(4):459-63.

28. Bettoli V, Manfredini M, Massoli L, et al. Rates of antibiotic resistance/sensitivity in bacterial cultures of hidradenitis suppurativa patients. J Eur Acad Dermatol Venereol. 2019;33(5):930-6.

29. Jamalpour M, Saki N, Nozari F. Microbial profile and antibiotic susceptibility of bacteria isolated from patients with hidradenitis suppurativa. Iran J Dermatol. 2019;22(1):25-9.

30. Nikolakis G, Liakou AI, Bonovas S, et al. Bacterial colonization in hidradenitis suppurativa/acne inversa: a cross-sectional study of 50 patients and review of the literature. Acta Derm Venereol. 2017;97(4):493-8.

31. Thomas C, Rodby KA, Thomas J, Shay E, Antony AK. Recalcitrant hidradenitis suppurativa: an investigation of demographics, surgical management, bacterial isolates, pharmacologic intervention, and patient-reported health outcomes. Am Surg. 2016;82(4):362-8.
32. Hessam S, Sand M, Georgas D, Anders A, Bechara FG. Microbial profile and antimicrobial susceptibility of bacteria found in inflammatory hidradenitis suppurativa lesions. Skin Pharmacol Physiol. 2016;29(3):161-7.

33. Katoulis AC, Koumaki D, Liakou AI, et al. Aerobic and anaerobic bacteriology of hidradenitis suppurativa: a study of 22 cases. Skin Append Disord. 2015;1(2):55-9.

34. Matusiak U, Bieniek A, Szepietowski JC. Bacteriology of hidradenitis suppurativa-which antibiotics are the treatment of choice? Acta Derm Venereol. 2014;94(6):699-702.

35. Sartorius K, Killasli H, Oprica C, Sullivan A, Lapins J. Bacteriology of hidradenitis suppurativa exacerbations and deep tissue cultures obtained during carbon dioxide laser treatment. Br J Dermatol. 2012;166(4):879-83.

36. Lapins J, Jarstrand C, Emtestam L. Coagulase-negative staphylococci are the most common bacteria found in cultures from the deep portions of hidradenitis suppurativa lesions, as obtained by carbon dioxide laser surgery. Br J Dermatol. 1999;140(1):90.

37. Brook I, Frazier EH. Aerobic and anaerobic microbiology of axillary hidradenitis suppurativa. J Med Microbiol. 1999;48(1):103-5.

38. Jemec G, Faber M, Gutschik E, Wendelboe P. The bacteriology of hidradenitis suppurativa. Dermatology. 1996;193(3):203-6.

39. Highet AS, Warren RE, Weekes AJ. Bacteriology and antibiotic treatment of perineal suppurative hidradenitis. Arch Dermatol. 1988;124(7):1047-51.

40. Kam S, Collard M, Lam J, Alani RM. Gut microbiome perturbations in patients with hidradenitis suppurativa: a case series. J Investig Dermatol. 2020. https://doi.org/10.1016/j.jid.2020.04.017.

41. Eppinga H, Sperna Weiland CJ, Thio HB, et al. Similar depletion of protective Faecalibacterium prausnitzii in psoriasis and inflammatory bowel disease, but not in hidradenitis suppurativa. J Crohns Colitis. 2016;10(9):1067-75.

42. Falagas ME, Siakavellas E. Bacteroides, Prevotella, and Porphyromonas species: a review of antibiotic resistance and therapeutic options. Int J Antimicrob Agents. 2000;15(1):1-9.

43. Lousada M, Lachnit T, Edelkamp J, et al. Exploring the human hair follicle microbiome. Br J Dermatol. 2020. https://doi.org/10.1111/bjd.19461. 
44. Mysak J, Podzimek S, Sommerova P, et al. Porphyromonas gingivalis: major periodontopathic pathogen overview. J Immunol Res. 2014;2014.

45. Larsen JM. The immune response to Prevotella bacteria in chronic inflammatory disease. Immunology. 2017;151(4):363-74.

46. Witte-Händel E, Wolk K, Tsaousi A, et al. The IL-1 pathway is hyperactive in hidradenitis suppurativa and contributes to skin infiltration and destruction. J Investig Dermatol. 2019;139(6):1294-305.

47. Schlapbach C, Hänni T, Yawalkar N, Hunger RE. Expression of the IL-23/Th17 pathway in lesions of hidradenitis suppurativa. J Am Acad Dermatol. 2011;65(4):790-8.

48. Jørgensen AHR, Thomsen SF, Karmisholt KE, Ring HC. Clinical, microbiological, immunological and imaging characteristics of tunnels and fistulas in hidradenitis suppurativa and Crohn's disease. Exp Dermatol. 2020;29(2):118-23.

49. Dinh KM, Erikstrup LT, Andersen R, et al. Crosssectional study identifies lower risk of Staphylococcus aureus nasal colonization in Danish blood donors with hidradenitis suppurativa symptoms. $\mathrm{Br}$ J Dermatol. 2020;183(2):387-9.

50. Katoulis A, Koumaki V, Efthymiou O, et al. Staphylococcus aureus carriage status in patients with hidradenitis suppurativa: an observational cohort study in a tertiary referral hospital in Athens, Greece. Dermatology. 2020;236(1):31-6.

51. Breuer K, Häussler S, Kapp A, Werfel T. Staphylococcus aureus: colonizing features and influence of an antibacterial treatment in adults with atopic dermatitis. Br J Dermatol. 2002;147(1):55-61.

52. Chehoud C, Rafail S, Tyldsley AS, Seykora JT, Lambris JD, Grice EA. Complement modulates the cutaneous microbiome and inflammatory milieu. Proc Natl Acad Sci. 2013;110(37):15061-6.

53. Katz SI, Strober W. The pathogenesis of dermatitis herpetiformis. J Investig Dermatol. 1978;70(2): 63-75.

54. Maarouf M, Platto JF, Shi VY. The role of nutrition in inflammatory pilosebaceous disorders: implication of the skin-gut axis. Australas J Dermatol. 2019;60(2):e90-8.

55. Cannistrà C, Finocchi V, Trivisonno A, Tambasco D. New perspectives in the treatment of hidradenitis suppurativa: surgery and brewer's yeast-exclusion diet. Surgery. 2013;154(5):1126-30.

56. Aboud C, Zamaria N, Cannistrà C. Treatment of hidradenitis suppurativa: surgery and yeast
(Saccharomyces cerevisiae)-exclusion diet. Results after 6 years. Surgery. 2020;167(6):1012-5.

57. Assan F, Gottlieb J, Tubach F, et al. Anti-Saccharomyces cerevisiae IgG and IgA antibodies are associated with systemic inflammation and advanced disease in hidradenitis suppurativa. J Allergy Clin Immunol. 2020;146(2):452-5.e5.

58. Quinton J, Sendid B, Reumaux D, et al. Anti-Saccharomyces cerevisiae mannan antibodies combined with antineutrophil cytoplasmic autoantibodies in inflammatory bowel disease: prevalence and diagnostic role. Gut. 1998;42(6): 788-91.

59. Chen W-T, Chi C-C. Association of hidradenitis suppurativa with inflammatory bowel disease: a systematic review and meta-analysis. JAMA Dermatol. 2019;155(9):1022-7.

60. Frew JW, Hawkes JE, Krueger JG. A systematic review and critical evaluation of inflammatory cytokine associations in hidradenitis suppurativa. F1000Research. 2018;7:1930.

61. Ring H, Thorsen J, Saunte D, et al. Moderate to severe hidradenitis suppurativa patients do not have an altered bacterial composition in peripheral blood compared to healthy controls. J Eur Acad Dermatol Venereol. 2018;32(1):125-8.

62. Frew JW. Hidradenitis suppurativa is an autoinflammatory keratinization disease: a review of the clinical, histologic, and molecular evidence. JAAD Int. 2020;1(1):62-72.

63. Perez Perez GI, Gao Z, Jourdain R, et al. Body site is a more determinant factor than human population diversity in the healthy skin microbiome. PLoS One. 2016;11(4):e0151990.

64. Gevers D, Knight R, Petrosino JF, et al. The Human Microbiome Project: a community resource for the healthy human microbiome. PLoS Biol. 2012;10(8): e1001377.

65. Turnbaugh PJ, Ley RE, Hamady M, Fraser-Liggett CM, Knight R, Gordon JI. The human microbiome project. Nature. 2007;449(7164):804-10.

66. Savin Z, Kivity S, Yonath H, Yehuda S. Smoking and the intestinal microbiome. Arch Microbiol. 2018;200(5):677-84.

67. Castaner O, Goday A, Park Y-M, et al. The gut microbiome profile in obesity: a systematic review. Int J Endocrinol. 2018;2018:4095789.

68. Naik HB, Piguet V. Standardizing hidradenitis suppurativa skin microbiome research: the methods matter. J Investig Dermatol. 2020;140(9):1688-90. 
69. Prast-Nielsen S, Tobin AM, Adamzik K, et al. Investigation of the skin microbiome: swabs vs. biopsies. Br J Dermatol. 2019;181(3):572-9.

70. Ardon CB, Prens E, Fuursted K, et al. Biofilm production and antibiotic susceptibility of Staphylococcus epidermidis strains from hidradenitis suppurativa lesions. J Eur Acad Dermatol Venereol. 2019;33(1):170-7.

71. Bing M, Forney L, Ravel J. The vaginal microbiome: rethinking health and diseases. Annu Rev Microbiol. 2012;66:371-89.

72. Walker AW, Duncan SH, Louis P, Flint HJ. Phylogeny, culturing, and metagenomics of the human gut microbiota. Trends Microbiol. 2014;22(5): 267-74.

73. Frew JW, Navrazhina K, Byrd A, et al. Defining lesional, perilesional and unaffected skin in hidradenitis suppurativa: proposed recommendations for clinical trials and translational research studies. Br J Dermatol. 2019;181(6):1339-41.

74. Jo J-H, Kennedy EA, Kong HH. Research techniques made simple: bacterial $16 \mathrm{~S}$ ribosomal RNA gene sequencing in cutaneous research. J Investig Dermatol. 2016;136(3):e23-7.

75. Kong $\mathrm{HH}$, Andersson B, Clavel T, et al. Performing skin microbiome research: a method to the madness. J Investig Dermatol. 2017;137(3):561-8.

76. Kathju S, Lasko L-A, Stoodley P. Considering hidradenitis suppurativa as a bacterial biofilm disease. FEMS Immunol Med Microbiol. 2012;65(2): 385-9.

77. Ring H, Bay L, Nilsson M, et al. Bacterial biofilm in chronic lesions of hidradenitis suppurativa. $\mathrm{Br} \mathrm{J}$ Dermatol. 2017;176(4):993-1000.
78. Fey PD, Olson ME. Current concepts in biofilm formation of Staphylococcus epidermidis. Future Microbiol. 2010;5(6):917-33.

79. Kimball AB, Kerdel F, Adams D, et al. Adalimumab for the treatment of moderate to severe hidradenitis suppurativa: a parallel randomized trial. Ann Intern Med. 2012;157(12):846-55.

80. Ribaldone DG, Caviglia GP, Abdulle A, et al. Adalimumab therapy improves intestinal dysbiosis in Crohn's disease. J Clin Med. 2019;8(10):1646.

81. Busquets D, Mas-de-Xaxars T, López-Siles M, et al. Anti-tumour necrosis factor treatment with adalimumab induces changes in the microbiota of Crohn's disease. J Crohns Colitis. 2015;9(10): 899-906.

82. Langan E, Künstner A, Miodovnik M, et al. Combined culture and metagenomic analyses reveal significant shifts in the composition of the cutaneous microbiome in psoriasis. $\mathrm{Br} \mathrm{J}$ Dermatol. 2019;181(6):1254-64.

83. Slocum C, Kramer C, Genco C. Immune dysregulation mediated by the oral microbiome: potential link to chronic inflammation and atherosclerosis. J Intern Med. 2016;280(1):114-28.

84. Ahn J, Chen CY, Hayes RB. Oral microbiome and oral and gastrointestinal cancer risk. Cancer Causes Control. 2012;23(3):399-404.

85. Machado MO, Stergiopoulos V, Maes M, et al. Depression and anxiety in adults with hidradenitis suppurativa: a systematic review and meta-analysis. JAMA Dermatol. 2019;155(8):939-45. 